\title{
PEQUI (CARYOCAR BRASILIENSE CAMB.). INFORMAÇÕES PRELIMINARES SOBRE UM PEQUI SEM ESPINHOS NO CAROÇO ${ }^{1}$
}

\author{
WARWICK ESTEVAM KERR² ${ }^{2}$ FRANCISCO RAIMUNDO DA SILVA², \\ BDIJAI TCHUCARRAMAE ${ }^{3}$
}

RESUMO: É relatado o achado de uma planta de pequi (Caryocar brasiliense Cambi) no Norte de Mato Grosso, sem espinhos no caroço (figuras 1 e 2 ).

O pequi é a $3^{\mathrm{a}}$ fruta mais consumida pelas populações do cerrado brasileiro e o seu único defeito é ter o caroço cheio de espinhos. Termos para indexação: melhoramento, seleção natural, descoberta.

\section{PEQUI (CARYOCAR BRASILIENSE CAMB.): PRELIMINARY INFORMATION ABOUT A PEQUI PLANT WITHOUT SPINES IN THE SEED KERNEL}

ABSTRACT - One pequi plant, (Caryocar brasiliense Camb. Caryocaraceae) whose fruits had no spines in the kernel, was found in the Noth of Mato Grosso (figures 1 and 2). This is the third most consumed fruit by the populations of the Brazilian Cerrado and its only deffect is to have the kernel full of spines. The history of its discovery is related.

Index terms: improvements, natural selection, discovery

\section{INTRODUÇÃO}

As Caryocaraceae são encontradas no neotrópico e têm dois gêneros: Anthodiscas (folhas opostas), cujas espécies vão de Santa Catarina até a Costa Rica, e Caryocar. O nome Caryocar vem do grego Karyon=noz, núcleo + caro= carne. Têm folhas alternas. Na Reserva Ducke (Manaus-AM), três espécies foram identificadas por Prance e Silva (1973): Caryocar glabrum, C.pallidum (=piquiarana), e C. villosum (=piquiá).Em Minas, São Paulo, norte do Paraná, Goiás, Mato Grosso, Tocantins, sull da Bahia, sul do Pará, sul do Maranhão, em todas as regiões de Cerrado, a espécie comum é a Caryocar brasiliense Camb. Os pequis florescem, na Amazônia, de agosto a dezembro e frutificam de novembro a março. Observamos que um conjunto de plantas do cerrado de Uberlândia floriu de 2 de abril de 2005 até 6 de maio de 2006.

Em todos os cerrados por que passamos, em época da floração, é comum que caçadores venham das 4 às 6 horas da manhã vigiar os pequizeiros em flor que as derrubam às centenas e atraem veados, pacas, cotias, porcos-espinho, capivaras, que têm especial predileção por elas. Isso é confirmado por Almeida et al. (1994). A produção é muito variável. A planta que produz pequi sem espinho no caroço, que encontramos, produziu ao redor de 500 frutos em 2004 e apenas 30 em 2005. Gribel (1986) constatou que $3 \%$ dos ovários de C. brasiliense se desenvolveram, mas apenas $1 \%$ chegou até semente. Morcegos são os grandes polinizadores. $\mathrm{O}$ mesmo autor informou que a dispersão dos frutos é realizada por gambás (Didelphis albiventris) e por uma gralha (Cyanocorax cristatelus). Em todas as áreas em que estivemos, o pequi é considerado afrodisíaco para os homens e fortificante para as mulheres grávidas. Essa segunda qualidade pode ser verídica devido à alta quantidade de vitamina A do pequi, já que 100 gramas de polpa comestível de pequi contém $20.000 \mathrm{mg}$ de vitamina A, $12 \mathrm{mg}$ de Vitamina C, $30 \mathrm{mg}$ de vitamina $\mathrm{B}, 463 \mathrm{mg}$ de riboflavina e $387 \mathrm{mg}$ de niacina (Franco,1982).Toda a população pobre dos estados brasileiros ocupados pelo pequi, de setembro a dezembro, consome o pequi em boa quantidade, com arroz, com carnes, em sopa, com angu, em doce de massa e na cachaça. A região do pequi ocupa quase 2.000 municípios e estima-se em cerca de 40.000 os coletores para vender os frutos ou os caroços aos compradores ou atravessadores. As milhares de pequenas farmácias e curandeiros das vilas e cidades dessa região, nessa época, são procurados por cerca de 3.000 pessoas (crianças e adultos) para retirarem os espinhos deixados pelos caroços no céu da boca de comedores descuidados. Essa característica é o principal defeito que elimina o pequi (Figura 1) de ser cultivado em casa e de sequer ser considerado uma fruta de mercado. É uma das frutas mais ricas em vitamina $A$, que é a principal deficiência alimentar dos pobres do Brasil.

O pequizeiro também é considerado árvore ornamental devido ao seu porte e à beleza das flores, que atraem beija-flores e diversas espécies de abelhas durante o dia. Todavia seus principais polinizadores são os morcegos e mariposas noturnas. As folhas do pequi são usadas em Minas e Goiás na alimentação do gado bovino, caprino, ovino e, em alguns lugares, das galinhas.Collevatti et al. (2003) estudaram 10 populações de

\footnotetext{
${ }^{1}$ (Trabalho 037-2007). Recebido em 01-02-2007. Aceito para publicação em 14-02-2007. Este trabalho é dedicado ao nosso amigo Helio do Carmo da Conceição, Prefeito de São José do Xingu, que nos informou sobre a existência desta planta, útil para a ciência

${ }^{2}$ Instituto da Genética e Bioquímica, Universidade Federal de Uberlandia. kerr@ufu.br

${ }^{3}$ Aldeia da Etnia Tchucarramae - Mato Grosso.
} 
Caryocar brasiliense e concluíram que múltiplas linhagens foram necessárias para dar origem às populações hoje existentes no Cerrado brasileiro. Melo Júnior et al. (2004), em um estudo em 4 lugares, Japonvar, Montes Claros, Francisco Sá e Bocaiúva, que compreendeu 240 plantas, concluíram: a) que houve um fluxo gênico muito grande, que atribuiu à polinização ser feita especialmente por morcegos que voam a longas distâncias. Há um alto índice de diversidade genética que sugere genes heteróticos. Também, constataram maior semelhança entre as populações de Japonvar, Montes Claros e Bocaiúva que atribuíram a menor distância entre elas $(35 \mathrm{~km})$. Indicaram que uma coleta de 82 matrizes é o valor mínimo de coleta para se manter a variabilidade Genética. Conhecido como a "carne dos pobres" no norte de Minas, o pequi apresenta um grande valor nutricional. Em $100 \mathrm{~g}$ de polpa de pequi, encontra-se 271,1 calorias, $13,5 \%$ de proteínas, além de vitaminas, cobre, ferro, etc . (Almeida \& Silva, 1995). Segundo Ribeiro (2000), além de sua relevância para a alimentação de famílias do Cerrado, o pequi também se constitui em fonte de renda para uma parcela da população da região. Muitas pesquisas vêm sendo feitas com o pequi devido a sua importância social. Minas Gerais e Goiás reúnem 63,8\% da produção nacional do pequi. Em Minas, apenas duas regiões são grandes produtoras: norte de Minas e Jequitinhonha. De toda a produção apenas $39 \%$ é vendida, evidenciando a importância do pequi para o auto-consumo das famílias coletoras e seus amigos. Da parcela comercializada, $79,4 \%$ é entregue a intermediários, $12,2 \%$ se destina à venda direta ao consumidor e 7,3\% vai para a indústria (Censo Agropecuário, 1996).

\section{DESCOBERTA PARA A CIÊNCIA DO PEQUI SEM ESPINHOS NO CAROÇO.}

No começo de outubro de 2004, um dos autores, Warwick Estevam Kerr, conversando sobre melhoramento de plantas com o Sr. Hélio do Carmo da Conceição (fazendeiro, Prefeito de São José do Xingu), que estava em Uberlândia tratando-se de câncer, informou-o de que, no norte do Tocantins, havia um fruticultor, Sr. Bdijai Tchucarramae, que possuía uma plantação com mais de 300 plantas de pequi, sendo que uma dessas plantas apresentava frutos sem espinhos no caroço (Figuras 1 e 2). Imediatamente, mediante suas indicações, organizamos uma mini-expedição para aquela região chefiada por outro dos autores, o Técnico Agrícola Francisco Raimundo da Silva. Conseguimos fundos do CNPq, condução da UFU, e no dia 07-11-04, na Caminhonete Mitsubshi da UFU e, dois motoristas saíram em direção a São José do Xingu com a finalidade de coletar sementes do pequizeiro em pauta. Lá chegando, o Técnico Francisco Raimundo da Silva tornou-se amigo do Sr. Bdijai Tchucarramae e conseguiu adquirir 9 sementes, e trazer alguns galhos. Das 9 sementes 7 germinaram. No mês de dezembro de 2005, uma nossa segunda expedição deslocou-se novamente até São José do Xingu e, dessa vez, o Técnico Francisco Raimundo da Silva conseguiu trazer 3 sementes e 15 galhos para tentar pegamento por estaquia. Como o pegamento foi zero, conseguimos fundos para enviar o Técnico Francisco Raimundo da Silva a Goiânia, por 6 dias, a fim de especializar-se

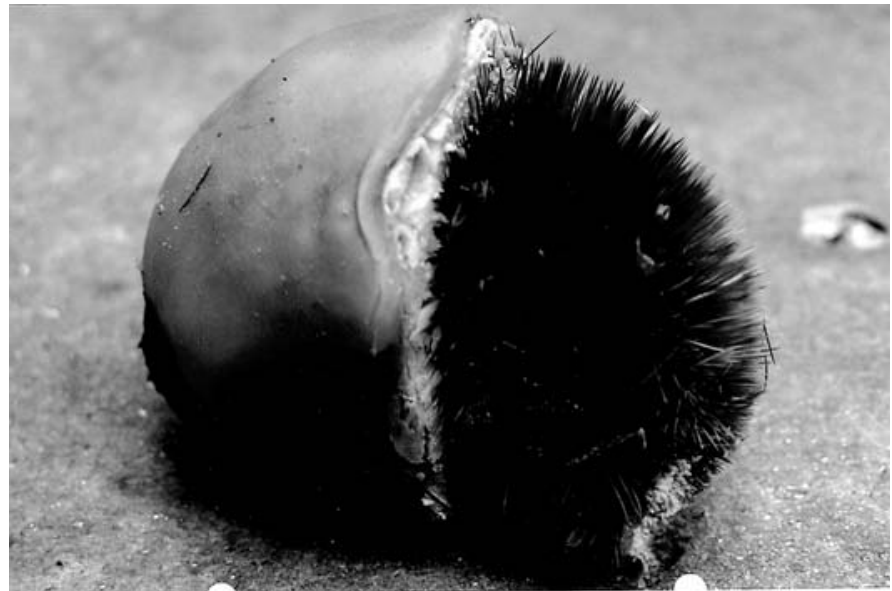

FIGURA 1 - Pequi com espinho no caroço
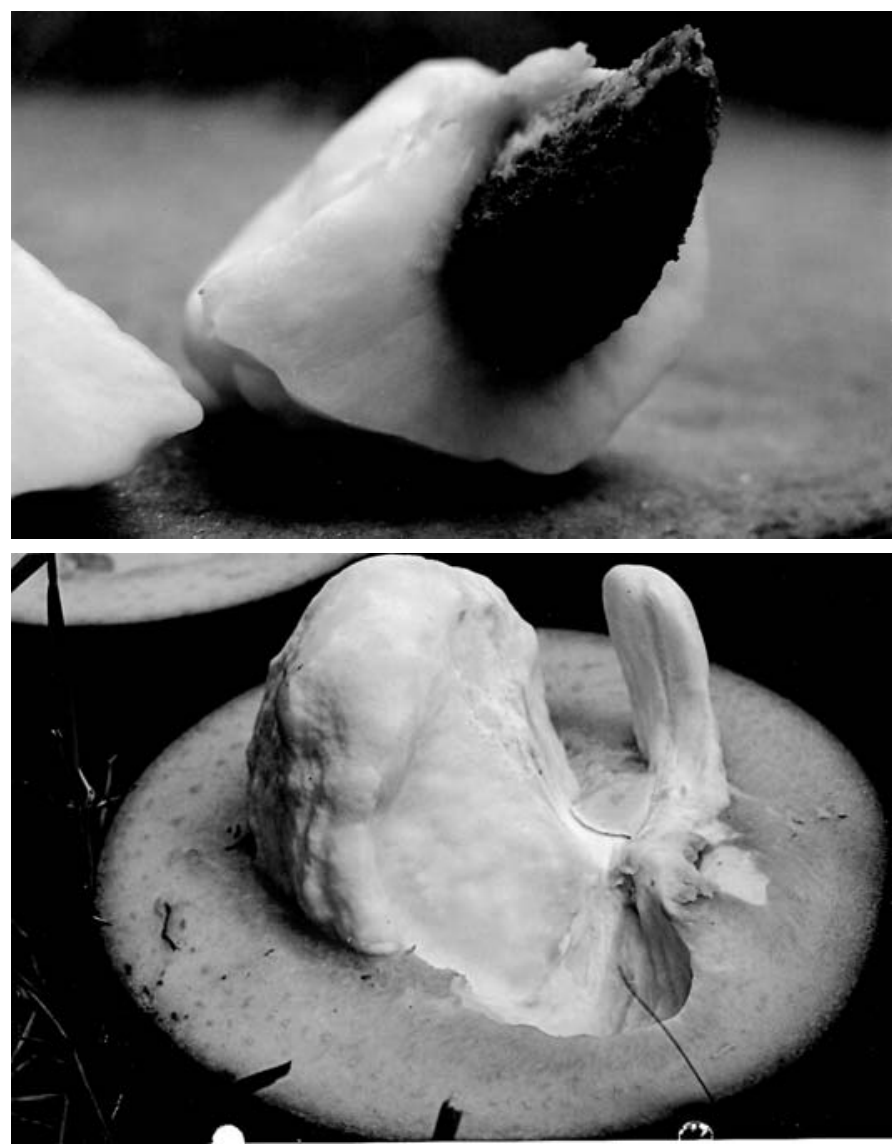

FIGURA 2 - Pequi sem espinhos no caroço

na enxertia de pequizeiro. Fez 6 enxertos, dos quais 4 pegaram. Assim, o fato de se ter encontrado uma planta que produz frutos com caroços sem espinhos e uma boa técnica de propagação, tornou-se uma esperança para, dentro de 4 a 8 anos, termos boa distribuição de mudas de pequi sem espinho no caroço. Também essa mutação tem todas as características para transformar o pequi numa fruta de mercado, tanto para as populações pobres como para mercados regulares de frutas nacionais e estrangeiras. Isso não somente melhorará o pequi para maior consumo, como também se poderá indicá-lo para plantio em pomares caseiros, aproveitando a alta apreciação que já possui. Todas as vezes 
que informamos que estamos trabalhando com "pequi sem espinho no caroço", obtemos imediata atenção e procura por sementes e mudas desse mutante. Todos que experimentaram os caroços carnudos, acharam-nos um pouco mais doces que os comuns e muito melhores devido à falta de espinhos.

\section{TESTES E ESTUDOS FUTUROS.}

Nosso atual objetivo é proporcionar o aumento da renda e a melhoria da nutrição das populações locais envolvidas na coleta e consumo do fruto do pequizeiro por meio do plantio de mudas enxertadas do pequizeiro mutante, sem espinhos no caroço. Assim que pudermos, dentro de 3 ou 4 anos, entregaremos mudas enxertadas aos principais laboratórios que se interessem por esse mutante. Entremente, alunos deste e de outros cursos universitários poderão pesquisar esta planta quanto as suas diferenças biológicas e bioquímicas.

\section{REFERÊNCIAS}

ADIS, J.; KERR, W. E. Um trips como praga do piquiá. Acta Amazônica, Manaus, v.9, n.4, p. 790, 1977.

ALMEIDA, S.P.de; SILVA, J.A. Oferta alimentar e componentes nutricionais de plantas nativas do cerrado. Brasília: EMBRAPA-CPCA, 1995/1994. (Documentos, 75)

ALMEIDA, S.P.: SILVA, J.A. Piqui e buriti: importância alimentar à população dos cerrados. Brasília: Documentos, 1994. p.138. (Documentos)

COLLEVATTI, R.G.; GRATTAPAGLIA, D.; HAY, J. Evidences for multiple maternal lineages of Caryocar brasiliense populations in the Brazilian Cerrado based on the analysis of chloroplast DNA sequences and micro satellite haplotype variation. Molecular Ecology, Oxford, v.12, p.105-115, 2003.

FRANCO, G. Nutrição: texto básico e tabela de composição química dos alimentos. 6. ed. Rio de Janeiro: Livraria Atheneu, 1998.

MELO JUNIOR, A. F. de; CARVALHO, D. de; PÓVOA, J.S.R. ; BEARZOLI, E. Estrutura genética de populações naturais de pequizeiro (Caryocar brasiliense Camb). Scientia Forestalis, Piracicaba, v.66, p.56-65, 2004.

GRIBEL, R. Ecologia da polinização e da dispersão de Caryocar brasiliense Camb. (Caryocararaceae) na região do Distrito Federal, Brasília. 1986. Dissertação (MSc) - Universidade de Brasília, Brasília, 1986.

GRIBEL, R.; HAY. J. D. Pollination ecology of Caryocar brasiliense (Caryocaraceae) in Central Brazil cerrado vegetation. Journal of Tropical Ecology, New York, v.9, n.2, p.199-211, 1993.

PRANCE, G.T.A.; SILVA, M. A monografia of Caryocaraceae: flore neotropica. New York: Organizatiom for Flora Neotropica, 1973. (Monografia, 12)

RIBEIRO, R.F. O Rei do cerrado. Belo Horizonte: Rede Cerrado/ CAA - NW/Campo Vale, 2000. 